university participation in research. But he acknowledged that the combined ministry probably represented only a "transitory stage" in Polish science planning.

In practice, all science and higher learning in Poland (save a small sector of basic research accounting for no more than 10 per cent of the total science and higher education budget) had to be linked to a complex hierarchy of "problems" of the national economy. This led to researchers trying to attach their projects to as high ranking a problem as possible, and to administrative difficulties when institutes wanted to renew books or equipment used jointly by all researchers.

By autumn 1980, it was accepted that the "problems" scheme had become inoperable and should be replaced by a looser structure of applied research based on contracts between industry and the research institutes or universities. But liberalization brought two other major problems into the open - the favoured position of institutes controlled by other ministries in the competition for funds and the strict separation of the universities from the academy.

In this respect, Poland has been an exception to the pattern of most Comecon countries, including the Soviet Union, where researchers in academy institutes can and do hold university teaching posts. The Polish arrangement has, at times, proved advantageous to individual scholars. Thus some of those who lost their university posts during the 1968 purge on the grounds of political unreliability found work within the academy network, where they had no direct contact with students.

Both these issues were raised and sympathetically discussed at the Solidarity Congress in September 1981, with the reservation that Poland already had too many graduates chasing too few jobs so that combining the roles of academy researcher and university lecturer might exacerbate the situation.

A third problem, little discussed outside the academy itself, is that the academy's academic secretary, a post of ministerial rank, is ultimately responsible not to the academy but to the Prime Minister. This, it was hoped, would be remedied by new legislation, a first draft of which was due for discussion by the academy general meeting in December 1981.

That meeting was pre-empted by the declaration of martial law, since when nothing has been heard of the promised legislation. Last month, however, the journal Rzeszpospolita, which follows an orthodox political line, suggested that the new law on the academy should be drafted and passed as soon as possible on the grounds that such a law might help to break down mistrust between the academy and the authorities, inducing Polish scholars to end their current stance of "internal emigration" - a euphemism for noncooperation with the authorities and the government.

Vera Rich

Ohio radiotelescope

\title{
Seeing stars or golf balls?
}

\section{Washington}

OHIO State University was abruptly informed last month that the land beneath its radio telescope - the fourth largest in the United States - is about to become the site of the Deleware Country Club's new golf course. University officials, who were apparently taken completely by surprise, are trying to work out a temporary arrangement with the country club, but there seems to be little chance that the telescope will be allowed to remain for more than five years.

Dr John Kraus, director of the radio observatory, calls the situation "a great scientific tragedy"'. An all-sky search for $21-\mathrm{cm}$ wavelength sources, completed two years ago at the observatory, catalogued 20,000 objects, including many undiscovered quasars, some of them the most distant quasars yet seen. At present, the chief work of the observatory is its participation in the National Aeronautics and Space Administration (NASA) search for extraterrestrial intelligence.

Although the observatory was built by Ohio State University (with funds from the National Science Foundation), the land it sits on was provided by Ohio Wesleyan University. Under the terms of this joint venture, the universities were to share in the use of the observatory, but Ohio Wesleyan's interest has apparently waned in the 25 years since it was built. Last October, Ohio Wesleyan offered the country club an option to buy a 250 -acre parcel and that includes the 100 acres currently leased by the club and 150 additional acres - among them the 15 acres occupied by the radio telescope.

According to Larry Thompson, assistant to the president of Ohio State, the university was told only after a contract for the sale had been signed.

A spokesman for Ohio Wesleyan says that its president, Thomas Wenzlau, had in fact discussed the sale of the land with the former provost of Ohio State two years ago, and that Ohio State "indicated they wanted to discontinue operation of the telescope by 1984 ".

"Ohio State showed no interest in

The threatened telescope

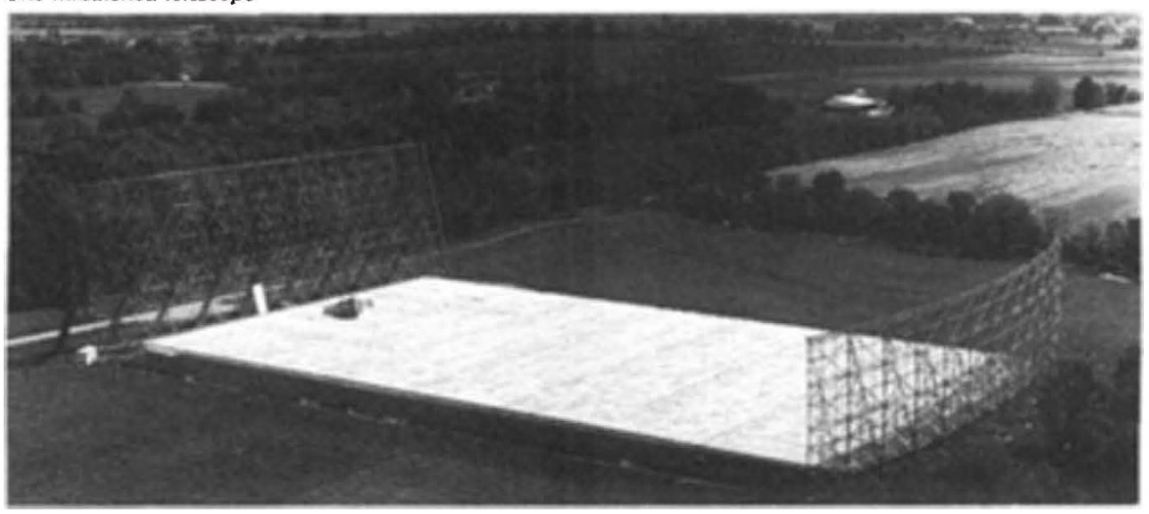

buying the property", he says. The spokesman suggested that the cause of the confusion may be the change in the Ohio State administration - both the provost and the president have left since that discussion took place. The spokesman adds that no Ohio Wesleyan faculty members now use the observatory and "we know of only one Ohio Wesleyan student who's used it in the last 10 years"

Ohio State officials have had one meeting with representatives of the country club to see if the telescope could remain. Earlin Harris, a member of the club who is involved in the negotiations, says, "I think all the issues will be resolved within a month of so", permanent solution. Dr Howard Sachs, associate provost at Ohio State, concedes that the university is in principle resigned to closing down the observatory. "The major problem is that we have only two faculty [members] right now who are intimately involved in its operation", he says. Kraus, the director, is one; he is a professor emeritus. The other is Dr Robert Dixon of the computer sciences department, who is not a full-time astronomer. The design of the telescope, which Kraus says provided the greatest aperture per unit cost, is tailored to the task of scanning the entire sky - making it of only limited use for most radioastronomy research.

Replacing the telescope would require an investment of $\$ 5$ million, according to Kraus; transporting it to a new location would be nearly as expensive. Sachs says that from the university's point of view, five years "would be a reasonable time" to try to keep the observatory open.

The country club has its own reasons for wanting to get rid of the observatory - and not just its plans to expand its nine-hole course to 18 holes. Sachs says the purchasers plan eventually to build residential units along the fairways. And the telescope, he admits, "is not the most desirable thing to have in your backyard. It looks like a couple of drive-in movie theaters that went out of business",

Stephen Budiansky
But the university does not expect a 